\title{
The impact of HIV-I on the malaria parasite biomass in adults in sub-Saharan Africa contributes to the emergence of antimalarial drug resistance
}

Jean-Pierre Van geertruyden*1, Joris Menten ${ }^{2}$, Robert Colebunders' ${ }^{3}$, Eline Korenromp ${ }^{4,5}$ and Umberto D'Alessandro ${ }^{1}$

Address: ${ }^{1}$ Department of Parasitology, Unit of Epidemiology Institute of Tropical Medicine Antwerpen, Nationalestraat 155 B2000, Antwerpen, Belgium, ${ }^{2}$ Department of Public Health, Institute of Tropical Medicine, Nationalestraat 155, B-2000, Antwerp, Belgium, ${ }^{3}$ Department of Clinical sciences, Institute of Tropical Medicine and University of Antwerp, Antwerp, Belgium, ${ }^{4}$ Department of Public Health, Erasmus MC, University Medical Centre Rotterdam, Rotterdam, The Netherlands and 5Performance Evaluation and Policy unit, The Global Fund to Fight AIDS, Tuberculosis and Malaria, Geneva, Switzerland

Email: Jean-Pierre Van geertruyden* - jpvangeertruyden@itg.be; Joris Menten - jmenten@itg.be; Robert Colebunders - bcoleb@itg.be; Eline Korenromp - Eline.Korenromp@TheGlobalFund.org; Umberto D'Alessandro - UDAlessandro@itg.be

* Corresponding author

Published: 22 July 2008

Malaria Journal 2008, 7:134 doi:10.1 186/1475-2875-7-134
Received: 25 February 2008

Accepted: 22 July 2008

This article is available from: http://www.malariajournal.com/content/7////34

(C) 2008 Van geertruyden et al; licensee BioMed Central Ltd.

This is an Open Access article distributed under the terms of the Creative Commons Attribution License (http://creativecommons.org/licenses/by/2.0), which permits unrestricted use, distribution, and reproduction in any medium, provided the original work is properly cited.

\section{Abstract}

Background: HIV-related immune-suppression increases the risk of malaria (infection, disease and treatment failure) and probably the circulating parasite biomass, favoring the emergence of drug resistance parasites.

Methods: The additional malaria parasite biomass related to HIV-I co-infection in sub-Saharan Africa was estimated by a mathematical model. Parasite biomass was computed as the incidence rate of clinical malaria episodes multiplied by the number of parasites circulating in the peripheral blood of patients at the time symptoms appear. A mathematical model estimated the influence of HIV-I infection on parasite density in clinical malaria by country and by age group, malaria transmission intensity and urban/rural area. In a multivariate sensitivity analysis, $95 \%$ confidence intervals $(\mathrm{Cls})$ were calculated using the Monte Carlo simulation.

Results: The model shows that in 2005 HIV-I increased the overall malaria parasite biomass by 18.0\% (95\% Cl: II.6-26.9). The largest relative increase (134.9-243.9\%) was found in southern Africa where HIV-I prevalence is the highest and malaria transmission unstable. The largest absolute increase was found in Zambia, Malawi, the Central African Republic and Mozambique, where both malaria and HIV are highly endemic. A univariate sensitivity analysis shows that estimates are sensitive to the magnitude of the impact of HIV-I infection on the malaria incidence rates and associated parasite densities.

Conclusion: The HIV-I epidemic by increasing the malaria parasite biomass in sub-Saharan Africa may also increase the emergence of antimalarial drug resistance, potentially affecting the health of the whole population in countries endemic for both HIV-I and malaria. 


\section{Background}

Since the 1980s, the epidemiological overlap of HIV-1/ AIDS and malaria in tropical regions, and particularly in Eastern and Southern Africa, has been cause for concern as even a small interaction between the two diseases may be of great public health importance [1-4]. HIV-1 and malaria coexist in regions where the health surveillance systems are poorly performing so that the magnitude of any interaction is difficult to determine. Nevertheless, the evidence of such interaction has recently grown and is still increasing. The incidence of symptomatic malaria episodes, severe or uncomplicated, and the corresponding parasite density is higher in HIV-1 infected individuals with low CD4 count [5].

It has been recently stated that, in Sub-Saharan Africa, the direct impact of HIV-1 infection on malaria morbidity and mortality is limited as the two diseases do not have the same geographical distribution and affect different age groups [6]. However, a model assessing the impact of HIV-1 on malaria in sub-Saharan Africa, estimated that in areas of unstable malaria transmission, such as southern Africa, the HIV-1 epidemic contributed to the increase of malaria observed in the 1990 s. Moreover, a recent mathematical model indicated a significant role for the dual infection in fueling the spread of both diseases in subSaharan Africa [7]. Besides a direct effect, HIV-1 infection may indirectly influence the malaria burden by increasing the malaria parasite biomass and consequently the probability of drug resistant parasites emerging. Antimalarial drug resistance, particularly for Plasmodium falciparum, is considered a major contributor to the global resurgence of malaria observed over the last three decades [8] and one of the greatest obstacles for an effective malaria control [9]. The basis of resistance lies in one or several genetic mutations in the parasite genome. Malaria parasites with such mutations when in contact with a given drug survive the treatment and eventually spread. Assuming that the occurrence of a de novo resistance mutation is evenly distributed among all parasites, a larger parasite biomass would increase the probability of new resistant strains emerging. Therefore, the additional malaria parasite biomass related to HIV-1 infection was estimated by reviewing the available literature on the impact of HIV-1 infection on malaria morbidity (incidence of clinical cases and parasite density) at individual level, and HIV-1 prevalence and malaria transmission intensity data at country level. The results of this analysis and the possible consequences of HIV-1 on the emergence of antimalarial drug resistance are reported and discussed below.

\section{Methods \\ Definition of endemicity}

The MARA ("Mapping Malaria Risk in Africa") climate suitability index was used for determining the country endemicity, i.e. high $\geq 0.75$ and low $<0.75$ [10]. However, Botswana, Namibia, South Africa, Swaziland, and Zimbabwe, because of their successful vector control programme, were not classified according to this criterion and despite a climate suitability index $>0.75$ were considered as low rather than high transmission areas [10].

\section{Malaria incidence and parasite density without HIV-I infection}

Incidence rates of symptomatic malaria (uncomplicated and severe) by transmission intensity and age group were collected from the available literature [6]. In high endemic rural areas the average incidence was estimated at 1.4 malaria episodes/person-year (py) among children $<5$ years of age, $0.59 /$ py in the $5-14$ year old and $0.11 /$ py in adults ( $\geq 15$ year old)[10]. In low endemic rural areas, incidence was estimated at $0.18 /$ py in children $<15$ years old and 0.09/py in those aged 15 years and above (Table 1). In high endemic urban areas, the malaria incidence was estimated to be similar to that in low endemic rural areas while in low endemic urban areas, the malaria incidence was estimated at half of the low endemic rural areas [11] (Table 1). In Botswana, Namibia, South Africa, Swaziland, and Zimbabwe, the average incidence was estimated at $0.03 /$ py [10], with the age pattern distribution similar to that of low endemic areas [6]. The proportion of urban dwellers was assumed not to vary by malaria endemicity. Urban and rural populations were based on countries' definitions, with no standardization between countries [12].

Geometric mean parasite density in falciparum malaria patients was usually between 5,000 and $50,000 / \mu \mathrm{l}$, with the lowest densities found where transmission was low and the highest where transmission was high [13]. In low endemic and in high endemic urban areas, the mean parasite density in clinical cases was assumed to be $30,000 / \mu \mathrm{l}$ in children $<5$ years old, $25,000 / \mu \mathrm{l}$ in those aged 5-14 years and $20,000 / \mu \mathrm{l}$ in patients aged $\geq 15$ years. In high endemic rural areas, the mean parasite density in clinical cases was assumed to be $30,000 / \mu \mathrm{l}$ for children $<5$ years old $_{1,} 20,000 / \mu \mathrm{l}$ for those aged 5-14 years, and $15,000 / \mu \mathrm{l}$ for patients aged $\geq 15$ years (Table 1 ). To allow the calculation of the population-level parasite biomass, the geometric mean parasite densities were converted into arithmetic means, by assuming that parasite densities in symptomatic malaria have an exponential distribution [14]. Arithmetic mean densities were therefore estimated at $51,347 / \mu$ l for children $<5$ years old, $42,789 / \mu$ l for those aged 5-14 years, and $34,231 / \mu$ l for patients aged $\geq 15$ years in low endemic and high endemic urban areas; in high endemic rural areas the corresponding figures by age group were $51,347 / \mu \mathrm{l}, 34,231 / \mu \mathrm{l}$ and $25,678 / \mu \mathrm{l}$. 
Table I: Assumptions on malaria incidence rates, parasite density, and effects of HIV-I, sub-Saharan Africa*

\begin{tabular}{|c|c|c|c|}
\hline \multirow[b]{2}{*}{ HIV-negative persons and HIV-infected persons with CD4 $\geq 500 / \mu \mathrm{l}$} & \multicolumn{3}{|c|}{ Age group } \\
\hline & $<5$ years & $5-14$ years & $\geq 15$ years \\
\hline \multicolumn{4}{|l|}{ Incidence of symptomatic malaria (per person-year) low/high endemicity[10] } \\
\hline Rural & $0.18 / 1.4$ & $0.18 / 0.59$ & $0.09 / 0.11$ \\
\hline Urban & $0.09 / 0.18$ & $0.091 / 0.18$ & $0.046 / 0.09$ \\
\hline $\begin{array}{l}\text { Proportion of symptomatic episodes with hyperparasitaemia (includes severe malaria): } \\
\text { low endemic and high endemic urban areas/high endemic rural areas }\end{array}$ & $4.0 \% / 4.0 \%$ & $4.0 \% / 1.5 \%$ & $4.0 \% / 1.5 \%$ \\
\hline $\begin{array}{l}\text { Geometric mean parasite density }(/ \mu \mathrm{L}) \text { in uncomplicated malaria: low endemic and high } \\
\text { endemic urban areas/high endemic rural areas [13] }\end{array}$ & $30,000 / 30,000$ & $25,000 / 20,000$ & $\begin{array}{l}20,000 / \\
15,000\end{array}$ \\
\hline $\begin{array}{l}\text { Geometric mean parasite density }(/ \mu \mathrm{L}) \text { in severe malaria (all age groups and } \\
\text { endemicities) }[20]\end{array}$ & & 458000 & \\
\hline Proportion of HIV-I patients [6] & with $C D 4<200 / \mu l$ & 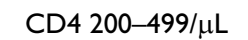 & \\
\hline Stabilized HIV epidemic & $37 \%$ & $25 \%$ & \\
\hline Rising HIV epidemic (e.g.Madagascar) & $22 \%$ & $15 \%$ & \\
\hline Relative change in HIV infection & with $C D 4<200 / \mu l$ & 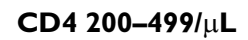 & \\
\hline $\begin{array}{l}\text { Relative risk of symptomatic malaria incidence (all age groups and endemicities) [I,2I- } \\
24]\end{array}$ & 5.0 & 3.0 & \\
\hline $\begin{array}{l}\text { Relative parasite density in symptomatic malaria } \\
\text { (all age groups and endemicities) (Table } 2 \text { ) }\end{array}$ & 3.0 & 1.5 & \\
\hline $\begin{array}{l}\text { Relative risk of progression to severe malaria (all age groups and endemicities) } \\
{[16,25,26]}\end{array}$ & 15.0 & 6 & \\
\hline Relative parasite density during severe malaria (all age groups and endemicities) & 1.0 & 1.0 & \\
\hline
\end{tabular}

A proportion of symptomatic malaria episodes evolves towards severe disease [15], generally with higher parasite densities than uncomplicated episodes. However, the sequestration of $P$. falciparum-infected erythrocytes in the deep circulation confounds the relationship between peripheral parasite density and disease severity [16-19]. It was assumed that $4 \%$ of clinical episodes both in low transmission (all age groups) and high (children) transmission areas evolve towards high parasite densities (some of them would have severe malaria). In high-transmission areas, $1.5 \%$ of all adult malaria episodes were assumed to be hyperparasitaemic at enrolment. Based on a recent model[20], these patients were assumed to have a geometric mean parasite density of 458,000 parasites $/ \mu \mathrm{L}$ $(309,659-678,910)$, corresponding to an arithmetic mean of 784,000 parasites/ $\mu \mathrm{L} \quad(530,000-1,162,000)$. Average blood volumes were estimated for each age group on the basis of heights and weights, i.e. one liter in the $<5$ years old, two liters for the 5-14 years old and five liters for the $\geq 15$ years old (range across human populations $0.25-8$ liters).

\section{Malaria incidence and parasite density with HIV-I infection}

The best evidence for an association between HIV infection and incidence of symptomatic malaria comes from four longitudinal population-based studies in rural Uganda and Malawi, where malaria is highly endemic. In Uganda, odds ratios of symptomatic malaria in HIVinfected compared to uninfected adults were 6.0, 3.4 and 1.2 for CD4 counts $<200 / \mu \mathrm{l}, 200-499 / \mu \mathrm{l}$ and $\geq 500 / \mu \mathrm{l}$, respectively [1]. In another study in Uganda, the incidence of symptomatic malaria in HIV-infected individuals varied according to CD4 count and was $0.14 / \mathrm{py}, 0.093 / \mathrm{py}$ and $0.057 /$ py for CD 4 count of $<200 / \mu \mathrm{L}, 200-499 / \mu \mathrm{L}$ and $>500 / \mu \mathrm{L}$, respectively $(0.09 / \mathrm{py}, 0.053 / \mathrm{py}$, and $0.022 /$ py when considering only episodes with more than 2,800 parasites $/ \mu \mathrm{L})$ [21]. In Malawi, incidence rates of symptomatic malaria in HIV-1 infected adults varied with CD4 count; compared to individuals with CD4 count of $\geq 500$, the malaria incidence was 3 -fold higher with a CD4 count of $200-499 / \mu \mathrm{L}$ and a 4.4 -fold higher with a CD4 count $<200 / \mu \mathrm{L}$ [22]. Another study from Malawi reports malaria incidence of 3.2/py, 4.9/py and 5.4/py in HIV-1 infected adults with CD 4 count of $\geq 400 / \mu \mathrm{L}, 200-399 / \mu \mathrm{L}$ and $<200 / \mu \mathrm{L}$, respectively [23]. In most of these studies malaria infection was not assessed at the time that CD4 count was done. This is a limitation as malaria itself causes a temporarily and reversible decrease in peripheral CD4 count (by one third) [24]. Therefore, the risk for clinical malaria may increase at a higher-than-expected CD4 count. We assumed that, compared to HIV-1 negative individuals, the risk of clinical malaria in HIV-1 infected individuals with a CD 4 count $<200 / \mu \mathrm{l}$ and $200-499 / \mu \mathrm{L}$ is 5 and 3-fold higher, regardless of endemicity and age. HIV-1 infected with a CD4 count $\geq 500$ were expected to have no additional risk.

HIV-1 infection considerably increases the risk of severe malaria in adults $[16,25,26]$. In South Africa, in an area of low (unstable) transmission, malaria-attributable mortality was nearly 7 -fold higher in HIV-infected malaria 
patients. Similar observations have been collected in an ongoing study in a meso-endemic region of Zambia, with the highest risk in HIV-1 infected with low CD4 count (Chalwe, unpublished data). We assumed that, compared to HIV-1 negative individuals, the risk of severe malaria in HIV-1 infected individuals with a CD 4 count $<200 / \mu$ l and $200-499 / \mu \mathrm{L}$ is 15 and 6-fold higher, regardless of endemicity and age. HIV-1 infected with a CD4 count $\geq 500$ were expected to have no additional risk.

\section{Parasite density in clinical malaria and HIV-I infection}

HIV-1 infection tends to increase the mean parasite density, although this effect is largely limited to patients with advanced immune suppression (Table 2). In HIV-1 infected individuals, the geometric mean parasite density in uncomplicated malaria was assumed to be three-fold higher at CD4 count $<200 / \mu \mathrm{l}$ and $50 \%$ higher at CD4 count $200-499 / \mu \mathrm{L}$, irrespective of malaria endemicity and patient's age. For severe malaria, because parasite density is already high and few data are available, it was conservatively assumed that parasite density does not vary according to HIV infection.

\section{HIV-I prevalence and CD4 counts in HIV-infected individuals}

Point estimates of national HIV-1 prevalence for 2005 are available from the Joint United Nations Programme on HIV/AIDS (UNAIDS) [27]. The impact of HIV infection was evaluated separately for urban and rural areas, because of varying intensity of malaria transmission. The urban-to-rural ratios in HIV-1 prevalence were estimated from national household surveys or antenatal clinic surveillance data $[27,28]$. For all countries, except Madagascar, it was assumed that $37 \%$ and $25 \%$ of HIV-infected people have a CD4 count $<200 / \mu \mathrm{L}$ and $200-499 / \mu \mathrm{L}$ respectively, a good approximation for the African populations where HIV prevalence has stabilized [6]. For Madagascar, where adult HIV prevalence is low but rising, 37\% of HIV-infected people were assumed to have a CD4 count $<500 \mu \mathrm{L}[6]$.

\section{HIV-I infection and parasite biomass increase at population level}

Annual parasite biomass was defined as the incidence rate (per person-year) of symptomatic (uncomplicated and severe) episodes multiplied by the total number of parasites circulating in the patient's peripheral blood at the time of the clinical episode (i.e. when parasite density is measured at a health facility). The parasite biomass was estimated for each country by age group $(<5,5-15$ and above 15 years), by urban/rural and by low and high endemicity taking into account the HIV-1 prevalence, the incidence rates of uncomplicated and severe (hyperparasitaemic) malaria and their corresponding parasite density. The overall country parasite biomass was computed by summing up the estimations for each category listed above.

To assess the sensitivity of the results, both univariate and multivariate sensitivity analyses were performed. In the univariate sensitivity analysis, the impact of HIV was recalculated for two alternative scenarios, corresponding to the lower and upper bound of the likely range. In the multivariate sensitivity analysis, 95\% confidence intervals were calculated using the Monte Carlo simulation in which 1,000 samples were taken from triangular distributions for all parameters [29] and the resulting proportional increase in parasite was calculated. All statistical analyses were performed using Microsoft Excel and the statistical software R version 2.2.1 [30].

\section{Results}

In sub-Saharan Africa (41 countries), the HIV-1 epidemic increases the malaria parasite biomass on average by 18.0\% (95\%CI: 11.6-26.9), ranging from 2.0\% in Madagascar to $243.9 \%$ in Swaziland. The highest proportional increases were found in Southern African countries, where HIV prevalence is the highest and malaria transmission unstable (Table 3, Figure 1).

In absolute terms, HIV-1 infection increased the annual malaria parasite biomass from $4.08^{*} 10^{19}$ (95\%CI: $\left.1.30-8.65^{*} 10^{19}\right)$ to $4.86 * 10^{19}$ $\left(95 \% \mathrm{CI}: 1.48-10.63^{*} 10^{19}\right)$. Within the countries, the median increase per person living in a malaria endemic area was $7.5^{*} 10^{9}$, ranging from $0.4^{*} 10^{9}$ in Somalia to $54.3^{*} 10^{9}$ in Mozambique (Table 3 ). The highest absolute increases were found in countries where both HIV prevalence and malaria endemicity were high (Table 3, Figure 2), i.e. Zambia, Malawi, Mozambique and the Central African Republic.

The sensitivity analysis (Table 4 ) shows that these estimates are sensitive to the magnitude of the impact of HIV1 infection on the malaria incidence rates and associated parasite densities, with the assumptions for uncomplicated episodes being more influential than those for severe episodes. Excluding the effect of HIV-1 in children did not markedly reduce the estimate of biomass increase because in this age group the HIV-1 prevalence is low. For all alternative scenarios, the country ranking of absolute or relative increases in parasite biomass remained unchanged (not shown). Combining the uncertainty ranges on assumptions for all parameters presented in Table 1, the overall $95 \% \mathrm{CI}$ for the estimated relative increase in parasite biomass would be 11.6-26.9\% (best estimate $18.0 \%$ ). 
Table 2: Overview of African studies on geometric mean parasite densities during uncomplicated symptomatic malaria, by HIV-I status of the patient

\begin{tabular}{|c|c|c|c|c|c|c|c|c|c|}
\hline \multirow{2}{*}{$\begin{array}{l}\text { Study } \\
\text { CHILDREN }\end{array}$} & \multirow{2}{*}{$\begin{array}{c}\text { Setting } \\
\text { HIGH } \\
\text { ENDEMICITY }\end{array}$} & \multirow[t]{2}{*}{$\begin{array}{l}\text { Median age } \\
\text { (range) }\end{array}$} & \multirow[t]{2}{*}{$\begin{array}{l}\text { \# patients (or } \\
\text { malaria episodes, } \\
\text { if indicated) }\end{array}$} & \multicolumn{3}{|c|}{$\begin{array}{c}\text { Parasite density, } \\
\text { HIV-positive vs. HIV negative } \\
\text { patients }\end{array}$} & \multicolumn{3}{|c|}{$\begin{array}{l}\text { Parasite density in HIV-infected: } \\
\text { immune-suppressed vs. not immune- } \\
\text { suppressed* }\end{array}$} \\
\hline & & & & Values & $\%$ change & P-value & Values & $\%$ change & P-value \\
\hline Shaffer [45] & Zaire, 1988 & $3.3 \mathrm{y}$ & I 66 (6 HIV+) & $\begin{array}{c}93325 \text { vs } 8913 / \\
\mu \mathrm{L}\end{array}$ & $947 \%$ & 0.04 & -- & & \\
\hline Mermin, 2004 [46] & Uganda, 200I-3 & $0-5 y$ & NR & $\begin{array}{c}154 \text { vs } 61 / 200 \\
\text { WBC }\end{array}$ & $152 \%$ & 0.03 & -- & & \\
\hline Kamya, 2006 [47] & Uganda, 2002-4 & $3 y$ & 1802 & $\begin{array}{c}28186 \text { vs } 20 \\
076 / \mu \mathrm{L}\end{array}$ & $40 \%$ & NS & -- & & \\
\hline Otieno, 2006 [19] & Kenya, 2003-4 & $11 \mathrm{~m}$ & 317 & $\begin{array}{c}48356 \text { vs } 47 \\
245 / \mu \mathrm{L}\end{array}$ & $2 \%$ & NS & -- & & \\
\hline $\begin{array}{l}\text { Greenberg, 2001 } \\
\text { [17] }\end{array}$ & DRC, 1986-8 & $5-21 \mathrm{~m}$ & 271 episodes & $\begin{array}{c}4173 \text { vs } 3854 / \\
\mu \mathrm{L}\end{array}$ & $8 \%$ & NS & $\begin{array}{c}\text { AIDS vs. HIV } \\
\text { positive: II } 256 \text { vs } \\
2394 / \mu \mathrm{L}\end{array}$ & $370 \%$ & 0.068 \\
\hline Taha, 1994 [48] & Malawi, 1989 & $0-18 \mathrm{~m}$ & 564 episodes & --- & & NS & --- & & \\
\hline $\begin{array}{l}\text { Colebunders, } 1990 \\
\text { [49] }\end{array}$ & Zaire, 1986-7 & $7 y$ & 59 & $\begin{array}{c}3210 \text { vs } 4 \text { I70/ } \\
\mu \mathrm{L}\end{array}$ & $-23 \%$ & NS & --- & & \\
\hline Muller, 1990 [50] & Uganda, 1989 & $11 \mathrm{~m}$ & 75 & --- & & NS & -- & & \\
\hline ADULTS & $\underset{\text { ENDEMICITY }}{\text { HIGH }}$ & & & & & & & & \\
\hline Mermin, 2004 [46] & Uganda, 200I-3 & $34 y$ & 90 episodes & -- & & NS & $\begin{array}{c}<200 \text { vs. } \geq 200 \\
\text { CD4/ } 4 \text { L: } 60 \text { vs. } 24 / \\
200 \text { WBC }\end{array}$ & $185 \%$ & 0.02 \\
\hline French [2I] & Uganda, 1995-98 & $31 y$ & 153 episodes & --- & & & $\begin{array}{l}\text { Association low } \\
\text { CD } 4 \leftrightarrow \text { high } \\
\text { parasite density }\end{array}$ & & 0.0001 \\
\hline Kamya, 2006 [47] & Uganda, 2002-4 & $28 y$ & 163 & $\begin{array}{c}20537 \text { vs I5 } \\
174 / \mu \mathrm{L}\end{array}$ & $35 \%$ & NS & --- & & \\
\hline Laufer, 2006 [22] & Malawi, 2002-3 & $31.7 y$ & 203 & --- & & & $\begin{array}{l}\text { Association low } \\
\text { CD4 } \leftrightarrow \text { high } \\
\text { parasite density }\end{array}$ & & 0.005 \\
\hline $\begin{array}{l}\text { Van geertruyden, } \\
2006[37]\end{array}$ & Zambia, 2003-5 & 27 у $(15-50)$ & 971 & $\begin{array}{c}87 I 5 \text { vs } 8538 / \\
\mu \mathrm{L}\end{array}$ & $2 \%$ & NS & $\begin{array}{c}<300 \text { vs. } \geq 300 \\
\text { CD4/ } / \mu \mathrm{L}: 10093 \\
\text { vs. } 7328 / \mu \mathrm{L}\end{array}$ & $37 \%$ & 0.03 \\
\hline Shah, 2006 [38] & Kenya, 2002-4 & Adults & 619 & $\begin{array}{c}\text { | I } 732 \text { vs } 9516 \text { | } \\
\mu \mathrm{L}\end{array}$ & $22 \%$ & NS & $\begin{array}{c}<200 \text { vs } \geq \\
200 C D 4 / \mu \mathrm{L}: 22 \\
515 \text { vs. } 8232 / \mu \mathrm{L}\end{array}$ & $173 \%$ & $<0.005$ \\
\hline $\begin{array}{l}\text { Francesconi, 200I } \\
\text { [18] }\end{array}$ & Uganda, 2000 & $25 y$ & 170 & -- & & NS & --- & & \\
\hline $\begin{array}{l}\text { Whitworth, } 2000 \\
\text { [I] }\end{array}$ & Uganda, 1990-98 & $35 y$ & 559 episodes & -- & & NS & $\begin{array}{l}\text { Association low } \\
\text { CD4 ↔ high } \\
\text { parasite density }\end{array}$ & & 0.02 \\
\hline Simooya [5I] & Zambia, 1988 & $>12 y$ & 170 & -- & & 0.10 & --- & & \\
\hline Muller, 1990 [50] & Uganda, 1989 & $26 y$ & 200 & --- & & NS & -- & & \\
\hline CHILDREN & $\begin{array}{c}\text { LOW } \\
\text { ENDEMICITY }\end{array}$ & & & & & & & & \\
\hline $\begin{array}{l}\text { Kalyesubula, } 1997 \\
\text { [18] }\end{array}$ & Uganda, 1988 & $0-4 y$ & 635 episodes & --- & & NS & --- & & \\
\hline $\begin{array}{l}\text { Grimwade, } 2003 \\
\text { [52] }\end{array}$ & $\begin{array}{c}\text { South Africa, } \\
2000\end{array}$ & $7 y$ & 663 & --- & & NS & --- & & \\
\hline ADULTS & $\begin{array}{c}\text { LOW } \\
\text { ENDEMICITY }\end{array}$ & & & & & & & & \\
\hline Atzori, 1993 [2] & Tanzania, 1991 & $|8-4|$ y & 300 & --- & & NS & --- & & \\
\hline $\begin{array}{l}\text { Grimwade, } 2004 \\
\text { [16] }\end{array}$ & $\begin{array}{c}\text { South Africa, } \\
2000\end{array}$ & $30 y$ & 613 & $16.7 \%$ vs $12.5 \% *$ & $34 \%$ & 036 & -- & & \\
\hline Birku, 2002 [36] & Ethiopia, 2000 & $31 y$ & 19 & $\begin{array}{c}27486 \text { vs } 32 \\
892 / \mu \mathrm{L}\end{array}$ & $-16 \%$ & NS & --- & & \\
\hline
\end{tabular}

Abbreviations: NS = non-significant; --. = Not reported; $m=$ months; $y=$ years; RR = relative risk; $W B C=$ white blood cells. *All studies except for [23] measured CD4 count during malaria episodes, which, due to the temporary decrease in CD4 caused by symptomatic malaria [24], probably inflated the CD4 threshold below which HIVrelated immune-suppression starts to increase malaria incidence. 


\section{Discussion Impact of HIV on parasite biomass}

The HIV-1 epidemic may have increased malaria parasite biomass in sub-Saharan Africa by $17.4 \%$. The highest absolute increases were found in countries with both high malaria and HIV burden (Zambia, Malawi, Mozambique and the Central African Republic). A recently published model [7] found that the largest epidemiological impact occurs when one baseline measure is very high while the other is very low and near its endemic threshold. When both prevalences were very high, the direct epidemiological impact of the interaction seemed to be minimal. It is indeed conceivable that, when both diseases reach an epidemic equilibrium, the epidemiological impact of the interaction will be minimal while the disease interaction should be maximal. Nevertheless, when both diseases are at epidemic equilibrium, there may be an indirect but important epidemiological impact such as the increased parasite biomass, higher biodiversity and higher probability of de novo resistance mutations emerging.

The model presented has several limitations. Pregnant women were not considered in the model as the parasite biomass in this high-risk group and its changes according to the HIV-1 infection could not be estimated, partly because of the sequestration of parasites in the placenta. Considering that pregnant women are particularly vulnerable to malaria infection and that such vulnerability is increased by HIV-1 infection, their exclusion may have led to an underestimation of the actual impact of HIV-1 infection at population level.

Moreover, the possible impact of HIV-1 infection on parasite density in asymptomatic individuals was not considered. This simplification may be justified because, due to the logarithmic distribution of malaria parasites in human populations, asymptomatic carriers, despite outnumbering the clinical cases, carry only a small proportion (probably less then 1/1000) of the world's potentially transmissible parasites [31,32]. In addition, asymptomatic infections most often are not treated, reducing the risk of selecting resistant parasites. In absence of drug pressure, mutant resistant parasites may be "less fit" and possibly less transmitted. However, once resistance has emerged and spread above a certain threshold, asymptomatic infections could play a substantial role for its further spread, especially in high endemic areas, and this effect could be enhanced by a higher prevalence of asymptomatic infection in HIV co-infected individuals. The spread of these resistant strains should be calculated by a stochastic model where asymptomatic carriers most probably play an important role.

An additional limitation of the model presented is the assumption that the effect of the HIV-1 infection on para- site density is constant throughout the clinical episode. This may not be true as the actual parasite density may vary throughout the clinical episode.

\section{Impact of HIV on the emergence of antimalarial drug resistance?}

Several factors determine the probability of selecting the de novo mutations linked to antimalarial drug resistance [33]. Amongst them, the frequency at which the resistance mutation occurs and the number of parasites in the human host exposed to the drug are considered as independent risk factors. If the probability of de novo resistance mutations is distributed evenly among all parasites then the biomass increment due to HIV-1 directly increases the rate at which these mutations occur.

Mathematical models of malaria epidemiology and drug resistance represent important tools in guiding malaria control strategies. They consistently predict that once drug resistance arises, it spreads rapidly, with the level of host immunity (both aspecific and specific) considered as an additional important independent factor. Although the dynamics underlying the spreads of antimalarial resistance may be much more complex than previously realized [34], the cycle of the emergence and subsequent spread of antimalarial drug resistance [35], and the influence of HIV-1-related immune-suppression can be schematically represented (Figure 3). Drug resistance starts with one or several genetic mutations in parasites which, if exposed to the drug, are selected and may spread. HIV-1 infection contributes to the emergence and spread of drug resistance by increasing drug exposure and drug pressure. HIV1 infection increases the probability of a malaria infection progressing to symptomatic illness and to a higher parasite densities, increasing the probabilities of treatment and contact between the parasites and the drug [1,21-23]. In addition, immune suppressed HIV-infected adults suffer frequently of non-malaria-attributable acute fevers that may be misdiagnosed as malaria and treated as such [22]. Once resistance has emerged and spread above a certain threshold, malaria treatment of non-malaria fever in HIV immune-suppressed individuals might contribute to the further spread of drug resistance by increasing the drug pressure on asymptomatic malaria infections. After treatment, a delayed cure rate [36] and a higher rate of recrudescence $[37,38]$, a phenomenon already described in HIV-1 infected individuals, accelerate the spread of resistant parasites and increase the parasite biomass in symptomatic patients and asymptomatic carriers alike.

Besides contributing to the emergence and spread of antimalarial drug resistance, $\mathrm{HIV}-1$ infection may influence and modify its expected geographical pattern. It has been postulated that antimalarial drug resistance first emerges and spreads in low-endemic areas, where the population 
Table 3: Estimated impact of HIV on malaria parasite biomass, sub-Saharan Africa, 2005*

\begin{tabular}{|c|c|c|c|c|c|c|}
\hline Country & Adult HIV prevalence & Urbant & $\begin{array}{c}\% \text { low-high } \\
\text { malaria endemic }\end{array}$ & $\begin{array}{c}\text { Parasite biomass*109 } \\
\text { /individual at risk in the } \\
\text { absence of } \mathrm{HIV} \ddagger\end{array}$ & $\begin{array}{l}\text { HIV-related additional } \\
\text { parasite biomass*109 } \\
\text { /individual at risk }{ }^{\ddagger}\end{array}$ & $\begin{array}{l}\text { Proportional increase in } \\
\text { parasite load due to } \\
\text { HIV } \\
(95 \% \mathrm{Cl})\end{array}$ \\
\hline Mozambique & $16.1 \%$ & $38 \%$ & $4-96$ & 77.2 & 54.3 & $64.0(41.0-95.8)$ \\
\hline Zambia & $17 \%$ & $36.5 \%$ & $16-83$ & 67.8 & 42.8 & $59.1(35.3-94.3)$ \\
\hline Malawi & $14.1 \%$ & $17.2 \%$ & $22-77$ & 75.3 & 40.2 & $54.1(26.4-96.8)$ \\
\hline CARepublic & $10.7 \%$ & $43.8 \%$ & $0-10$ & 76.6 & 32.2 & $41.9(23.4-77.3)$ \\
\hline Uganda & $6.5 \%$ & $12.4 \%$ & $20-73$ & 75.3 & 20.6 & $25.2(14.4-37.0)$ \\
\hline Togo & $6.7 \%$ & $36.3 \%$ & $0-100$ & 82.2 & 19.1 & $22.1(13.2-35.1)$ \\
\hline Cote d'Ivoire & $7.1 \%$ & $45.8 \%$ & $0-100$ & 75.9 & 19.1 & $23.4(14.2-39.1)$ \\
\hline Congo & $5.3 \%$ & $54.4 \%$ & $0-100$ & 62.5 & 13.2 & | $8.6(9.8-29.3)$ \\
\hline Swaziland & $33.4 \%$ & $23.9 \%$ & $69-0$ & 5.6 & 12.8 & $243.9(122.1-402.3)$ \\
\hline Gabon & $7.9 \%$ & $85.2 \%$ & $0-96$ & 38.5 & 12.5 & $30.7(19.6-53.0)$ \\
\hline Nigeria & $3.9 \%$ & $48.3 \%$ & $1-99$ & 70.8 & 12.0 & $16.7(9.4-26.6)$ \\
\hline Guinea-Bissau & $3.8 \%$ & $35.6 \%$ & $0-100$ & 78.9 & $1 \mathrm{I} .4$ & $13.9(7.9-23.6)$ \\
\hline Cameroon & $5.4 \%$ & $52.9 \%$ & $24-74$ & 53.3 & 11.3 & $20.1(|3.3-3| .2)$ \\
\hline Chad & $3.5 \%$ & $25.8 \%$ & $14-86$ & 76.3 & 11,2 & I5.I (6.4-23.9) \\
\hline Gambia & $2.4 \%$ & $26.1 \%$ & $0-100$ & 95.4 & 10.8 & I I.3 (5.8-19.0) \\
\hline Botswana & $24.1 \%$ & $52.5 \%$ & $13-0$ & 4.9 & 9.3 & $197.6(116.5-278.9)$ \\
\hline DRCongo & $3.2 \%$ & $32.7 \%$ & $10-85$ & 73.7 & 9.2 & $12.2(6.5-20.4)$ \\
\hline Liberia & $4 \%$ & $47.9 \%$ & $0-100$ & 69.2 & 9.1 & $12.2(7.3-2 \mid .5)$ \\
\hline Equat Guinea & $3.2 \%$ & $50 \%$ & $02-97$ & 68.1 & 8.4 & II.7 (7.1-18.0) \\
\hline Tanzania & $3.2 \%$ & $37.5 \%$ & $21-75$ & 65.0 & 7.8 & $11.2(5.8-19.4)$ \\
\hline Zimbabwe & $20.1 \%$ & $35.9 \%$ & $54-0$ & 5.2 & 7.5 & $144.2(75.6-221.0)$ \\
\hline Ghana & $2.3 \%$ & $46.3 \%$ & $02-98$ & 76.1 & 7.5 & $9.2(5.5-13.5)$ \\
\hline Namibia & $19.6 \%$ & $33.5 \%$ & $8-0$ & 5.3 & 7.1 & $134.9(74.4-247.1)$ \\
\hline South Africa & $18.8 \%$ & $57.9 \%$ & $15-0$ & 5.0 & 6.8 & $137.0(84.5-212.1)$ \\
\hline Burkina Faso & $2 \%$ & $18.6 \%$ & $0-100$ & 94.9 & 6.5 & $6.8(3.7-10.9)$ \\
\hline Sudan & $2.3 \%$ & $40.8 \%$ & $42-56$ & 48.9 & 5.8 & $13.4(4.2-28.3)$ \\
\hline Kenya & $6.1 \%$ & $47.9 \%$ & $57-21$ & 22.8 & 5.7 & $25.6(15.3-37.7)$ \\
\hline Angola & $3.7 \%$ & $37.2 \%$ & $53-46$ & 38.9 & 5.7 & $14.7(8.8-23.4)$ \\
\hline Mali & $1.7 \%$ & $33.7 \%$ & $10-90$ & 72.7 & 5,0 & $6.5(3.7-10.0)$ \\
\hline Guinea & $1.5 \%$ & $36.5 \%$ & $01-99$ & 81.0 & 5.0 & $5.6(3.3-8.3)$ \\
\hline Benin & $1.8 \%$ & $46.1 \%$ & $0-100$ & 73.7 & 5.0 & $6.4(3.6-10.4)$ \\
\hline Burundi & $3.3 \%$ & $10.6 \%$ & $64-21$ & 29.9 & 4.1 & $13.5(8.0-18.9)$ \\
\hline Niger & $1.1 \%$ & $23.3 \%$ & $11-89$ & 79.4 & 2.8 & $3.5(1.8-6.6)$ \\
\hline Sierra Leone & $1.6 \%$ & $40.2 \%$ & $0-100$ & 78.9 & 2.7 & $3.6(1.7-5.8)$ \\
\hline Senegal & $0.9 \%$ & $51 \%$ & $03-97$ & 68.1 & 2.6 & $3.9(2.1-6.4)$ \\
\hline Eritrea & $2.4 \%$ & $20.8 \%$ & $83-16$ & 19.5 & 2.3 & II.4 (5.8-19.8) \\
\hline Ethiopia & $2 \%$ & $16.2 \%$ & $50-14$ & 25.7 & 2.0 & $8.2(3.8-13.3)$ \\
\hline Rwanda & $3.1 \%$ & $21.8 \%$ & $60-7$ & 14.3 & 2,0 & $13.8(8.1-19.0)$ \\
\hline Mauritania & $0.7 \%$ & $64.3 \%$ & $59-41$ & 25,4 & 1.3 & $5.3(1.9-10.5)$ \\
\hline Madagascar & $0.5 \%$ & $27 \%$ & $36-60$ & 58.3 & 1.1 & $2.0(0.9-3.7)$ \\
\hline Somalia & $0.9 \%$ & $35.9 \%$ & $96-3$ & 7.2 & 0.4 & $5.6(2.5-9.2)$ \\
\hline Average Africa ${ }^{\$}$ & $6.1 \%$ & & $23-87$ & 55.1 & 9.9 & $18.0 \%(11.6-26.9)$ \\
\hline Median Africa & $3.5 \%$ & $36.5 \%$ & $11-83$ & 68.0 & 7.5 & I 4.1 (9.2-20.5) \\
\hline
\end{tabular}

*Excluded from analyses were the following small countries: Seychelles, Reunion and Comoros, which are at negligible malaria risk and the islands of Sao Tome \& Principe and Cap Verde, which are subject to stable transmission but have not been precisely characterized in the malaria risk model. Calculations used country-specific age distributions, based on HIV-I prevalence estimates by UNAIDS/World Health Organization (WHO) for end of 2005[27], and assuming urban/rural ratios in HIV prevalence estimated by UNAIDS/WHO) for end of 2003 [27,28] † Urban and rural populations were based on countries' definitions [12], without standardization between countries.

$¥$ Individual at risk is person living in a malaria prone area.

$\$$ Weighted according to countries' population size living in malaria endemic areas. 


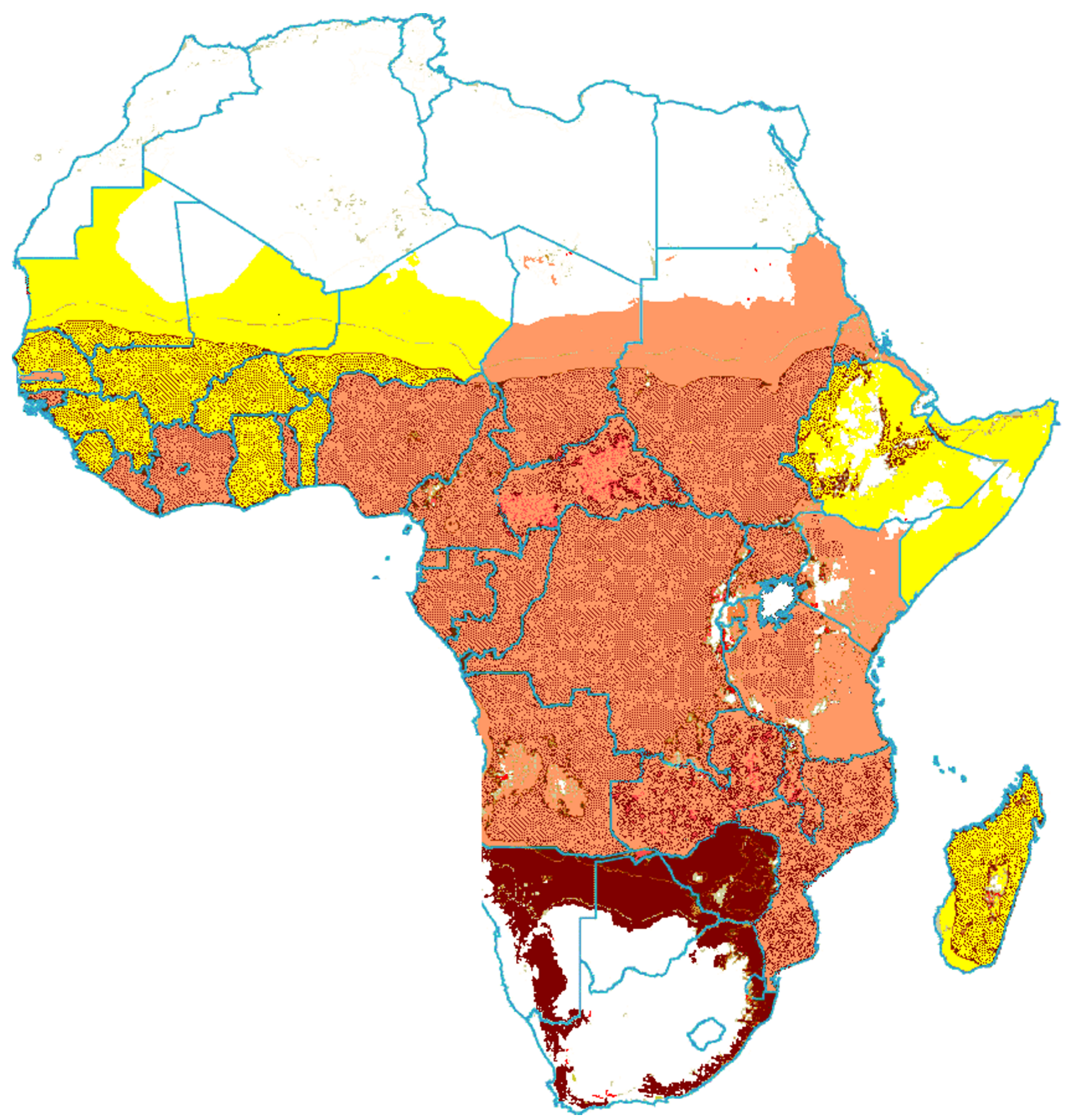

\section{Figure I}

Additional parasite biomass due to HIV-I in individuals living in malaria risk. No Malaria Transmission $<10 \%$ Parasite Biomass increase* 10-99\% Parasite Biomass increase* $\geq 100 \%$ Parasite Biomass increase* *High Malaria Transmission areas shaded.

acquired immunity is so low that most infections are symptomatic and thus treated, exposing a large numbers of parasites to antimalarial drugs [39]. In highly endemic areas, less malaria infections become symptomatic and are treated (especially in adults). In sub-Saharan Africa, when considering the geographical distribution of both 


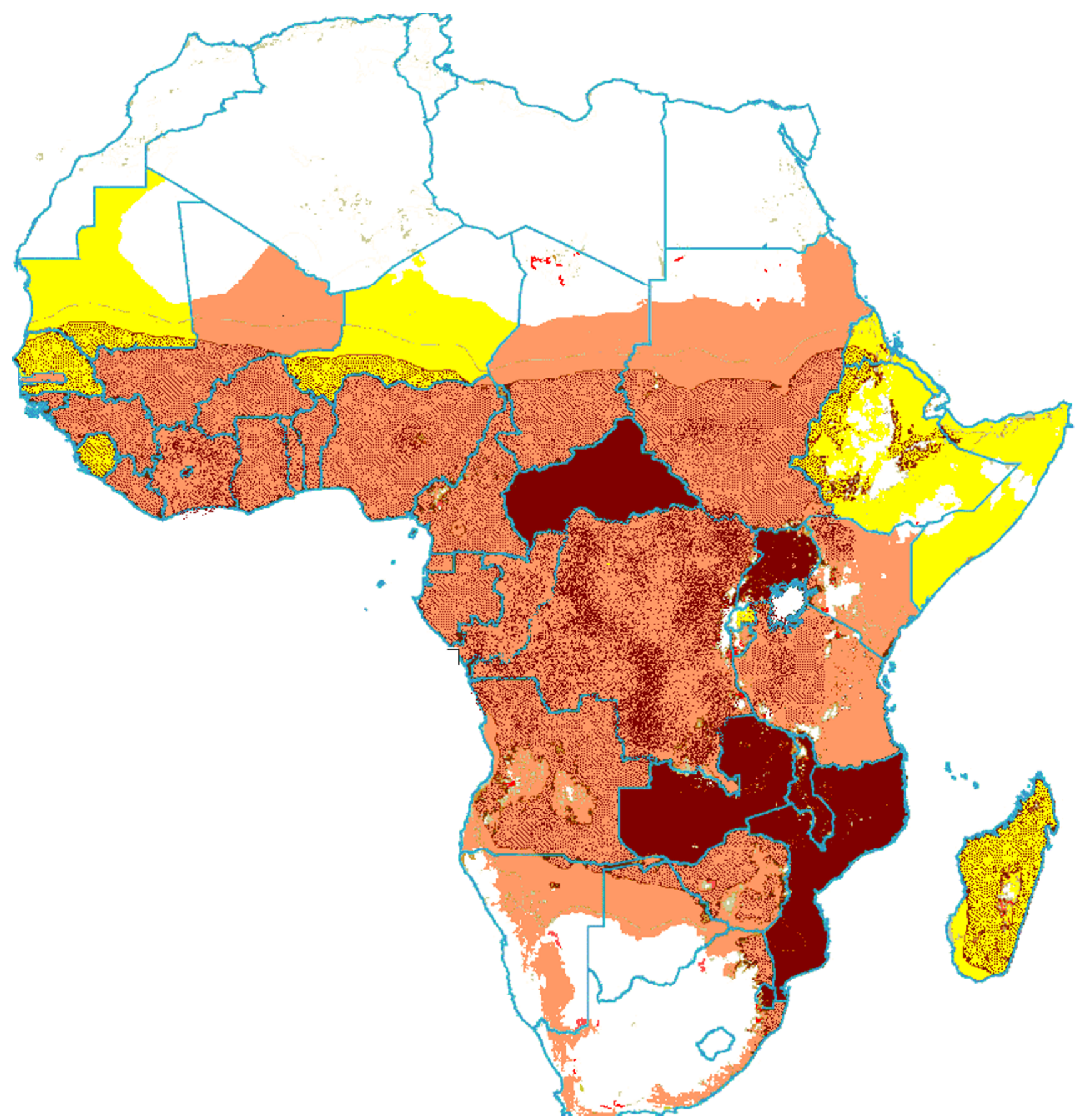

\section{Figure 2}

Additional parasite biomass due to HIV-I in individuals living in malaria risk areas in absolute terms *. No Malaria Transmission
$\begin{array}{ll}\text { risk increase* } \\ \text { shaded. }\end{array}$

the HIV-1 infection and the spread of drug resistance (to chloroquine and sulphadoxine-pyrimethamine) [33,40], the latter having been faster in eastern-southern (high
HIV-1 prevalence) than in western Africa (relatively low HIV-1 prevalence) [41], the question on the role of HIV-1 pandemic as an additional contributing factor could be 
Table 4: Sensitivity analyses on the estimated relative increase in Plasmodium falciparum parasite biomass due to HIV-I, sub Saharan Africa*

Relative increase parasite biomass

Best estimate $(95 \% \mathrm{Cl})^{*}$

$18.0 \%(11.6-26.9)$

\begin{tabular}{|c|c|c|c|c|}
\hline Parameters & Lower-bound assumption & Upper-bound assumption & Lower-bound assumption & Upper-bound assumption \\
\hline $\begin{array}{l}\text { HIV prevalence } \\
\text { (UNAIDS country point } \\
\text { estimate) }\end{array}$ & lower-bound & higher-bound & $11.4 \%$ & $23.8 \%$ \\
\hline $\begin{array}{l}\text { Relative risk of incidence of } \\
\text { uncomplicated } \\
\text { symptomatic malaria, in } \\
\text { HIV-infected individuals } \\
\text { with CD } 4<200 / \mu \text { and CD4 } \\
200-499 \text { compared to HIV- } \\
\text { negatives }\end{array}$ & $4 / 2$ & $6 / 4$ & $15.8 \%$ & $19.4 \%$ \\
\hline $\begin{array}{l}\text { Relative parasite density } \\
\text { during uncomplicated } \\
\text { symptomatic malaria, in } \\
\text { HIV-infected patients with } \\
\text { CD4<200/ } \mu \text { and CD4 } \\
200-499 / \mu \mathrm{L} \text { compared to } \\
\text { HIV-uninfected patients }\end{array}$ & $2 / 1$ & $4 / 2$ & $15.5 \%$ & $19.9 \%$ \\
\hline $\begin{array}{l}\text { Relative risk of progression } \\
\text { to severe malaria, in HIV- } \\
\text { infected individuals with } \\
C D 4<200 / \mu \mathrm{l} \text { and CD4 } \\
200-499 / \mu \mathrm{L} \text { compared to } \\
\text { HIV-uninfected patients }\end{array}$ & $8 / 3$ & $24 / 12$ & $17.2 \%$ & $18.6 \%$ \\
\hline $\begin{array}{l}\text { Relative parasite density } \\
\text { during severe malaria, in } \\
\text { HIV-infected patients with } \\
\text { CD4<500/ul compared to } \\
\text { HIV-uninfected patients }\end{array}$ & $0.5 / 0.5$ & $2.0 / 2.0$ & $16.9 \%$ & $18.2 \%$ \\
\hline \multicolumn{3}{|c|}{$\begin{array}{l}\text { Assume no HIV-I impact on incidence of symptomatic malaria, severe malaria or } \\
\text { parasite density in children under } 15 \text { years }\end{array}$} & $17.6 \%$ & n.a. \\
\hline \multicolumn{3}{|c|}{$\begin{array}{l}\text { Mean parasite density during uncomplicated symptomatic malaria in HIV-negative } \\
\text { patients equal for all age groups and endemicities: } 20000 / \mu \mathrm{L}\end{array}$} & n.a. & $17.2 \%$ \\
\hline
\end{tabular}

* For default values underlying this best estimate, see Table 2.

raised. It is impossible to provide a definitive answer though the results of the model presented in this paper are compatible with an influence of HIV-1 infection on the epidemiology of antimalarial drug resistance.

Malaria parasite biomass is influenced through various malaria control interventions. Easy access, prompt diagnosis and efficacious treatment with combination therapy are essential to halt or delay the emergence and spread of antimalarial drug resistance [9]. The artemisinin derivatives, commercialized in the last decade, are the most potent antimalarial drugs with parasite reduction levels of 10,000 per cycle. Furthermore, if used in combination, the artemisinin component is protected by the partner drug and the parasite reduction rate is positively affected. Unfortunately, it is still unclear how treatment combinations for both malaria and HIV-1 interact. More data on the biological effects of therapy combinations would be of great utility to complement recent 'in vitro' evidence of a synergistic effect between protease inhibitors and antimalarials [32]. Preventive interventions are equally important as they diminish the parasite load, transmission and drug pressure. Indeed, the incidence of symptomatic malaria in HIV-infected adults can decrease by $95 \%$ by giving cotrimoxazole prophylaxis and antiretroviral treatment combined with insecticide-treated bed nets [42]. Furthermore, next to individual protection, preventive activities as indoor residual spraying, use of bed nets and cotrimoxazole prophylaxis reduce the parasite biomass at community level. For indoor residual spraying this is quite obvious as it is a community intervention but it has been shown that cotrimoxazole prophylaxis taken by HIV-infected people was associated with decreased morbidity and mortality among family members [43]. Recent modeling has demonstrated that insecticide-treated nets protection has a substantial impact on the circulating 


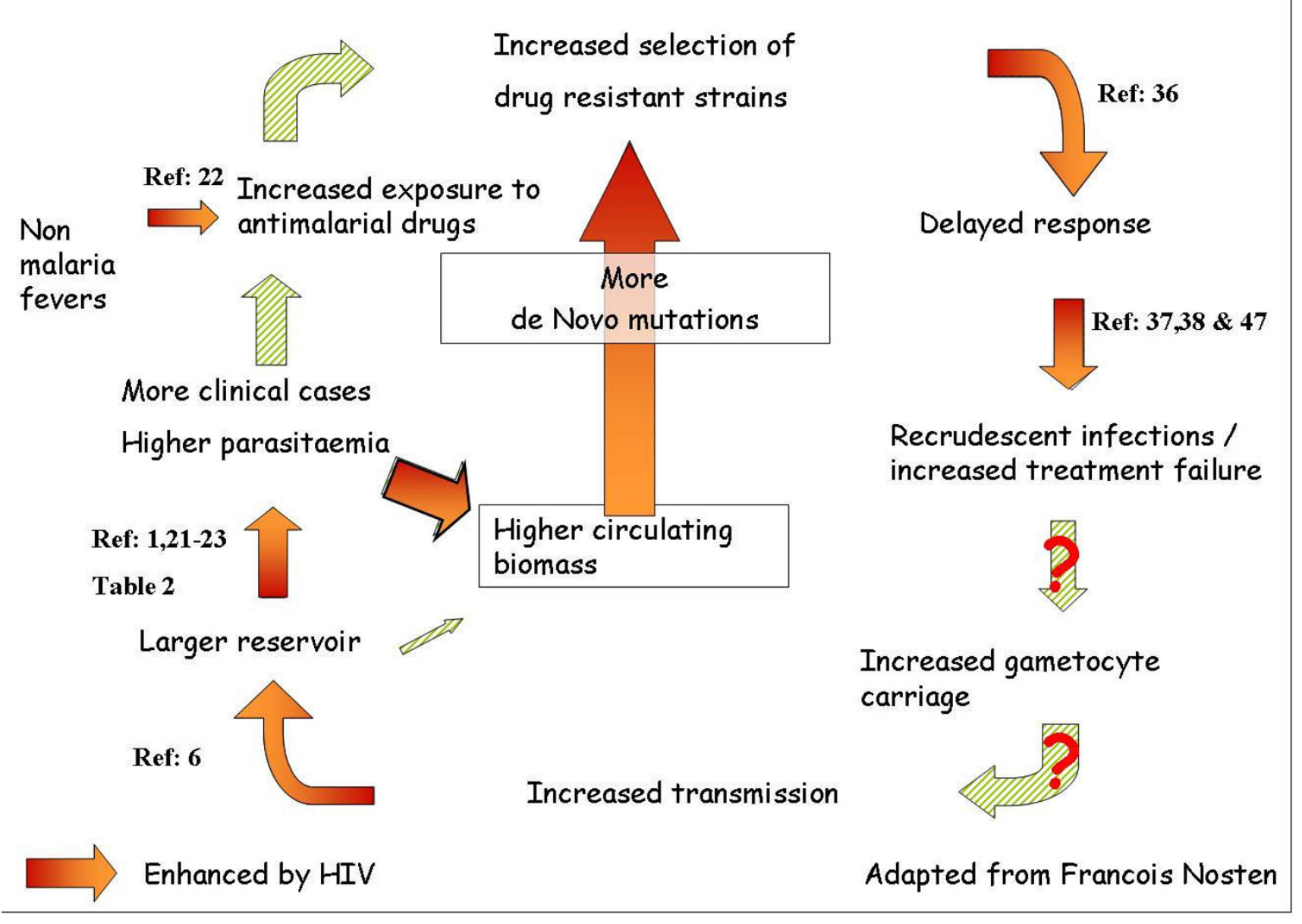

Figure 3

Effects of HIV on the emergence and consequent spread of antimalarial drug resistance in human populations.

malaria parasite biomass and has community-wide benefits that are often underestimated [44]. Therefore, during the ongoing scale-up of HIV/AIDS and malaria control measures, HIV-1 infected individuals should be considered a priority group for the distribution of insecticidetreated nets, co-trimoxazole prevention and artemisininbased combination therapy.

\section{Conclusion}

Earlier studies on the impact of HIV infection on malaria morbidity and mortality focused on the direct effects in HIV-infected people. They concluded that the populationlevel effect was limited because of different geographical distribution and contrasting age patterns of the two diseases. However, the model presented suggests that the overall impact of HIV-1 infection may be greater than previously estimated. If HIV-1 is a major contributing factor for the emergence of antimalarial drug resistance, this will have a major impact over the whole population by increasing malaria morbidity and mortality. A second stochastic model dealing with the contribution of HIV-1 infection on the spread of antimalarial drug resistance once resistance has emerged is currently under development.

Preventive interventions, easy access, prompt diagnosis and efficacious treatment with combination therapy are essential to diminish the parasite biomass, transmission and drug pressure and halt or delay the emergence and spread of antimalarial drug resistance [9]. This is even more important for HIV-1 infected malaria patients. Targeting this vulnerable group will greatly contribute to malaria control and will benefit the whole population in endemic countries. 


\section{Authors' contributions}

JPVg developed the model, did the literature research, did the analyses and wrote the paper. JM worked out the model in $\mathrm{R}^{\circledast}$. RC reviewed the paper. EK contributed to analyses and writing of the paper. UDA contributed to the data interpretation and the writing of the paper. All authors read and approved the final manuscript.

\section{Conflict of interest stated}

The authors declare that they have no competing interests.

\section{Acknowledgements}

Thanks to lan Hastings, Brian Greenwood and Feiko Ter Kuile for useful comments on earlier versions of the manuscript.

\section{References}

I. Whitworth J, Morgan D, Quigley M, Smith A, Mayanja B, Eotu H, Omoding N, Okongo M, Malamba S, Ojwiya A: Effect of HIV-I and increasing immunosuppression on malaria parasitaemia and clinical episodes in adults in rural Uganda: a cohort study. Lancet 2000, 356:1051-1056.

2. Atzori C, Bruno A, Chichino G, Cevini C, Bernuzzi AM, Gatti S, Comolli G, Scaglia M: HIV-I and parasitic infections in rural Tanzania. Ann Trop Med Parasitol 1993, 87:585-593.

3. Steketee RW, Wirima JJ, Bloland PB, Chilima B, Mermin JH, Chitsulo L, Breman JG: Impairment of a pregnant woman's acquired ability to limit Plasmodium falciparum by infection with human immunodeficiency virus type-I. Am J Trop Med Hyg 1996, 55:42-49.

4. Verhoeff FH, Brabin BJ, Hart CA, Chimsuku L, Kazembe P, Broadhead RL: Increased prevalence of malaria in HIV-infected pregnant women and its implications for malaria control. Trop Med Int Health 1999, 4:5-12.

5. Hewitt K, Steketee R, Mwapasa V, Whitworth J, French N: Interactions between HIV and malaria in non-pregnant adults: evidence and implications. AIDS 2006, 20:1993-2004.

6. Korenromp EL, Williams BG, de Vlas SJ, Gouws E, Gilks CF, Ghys PD, Nahlen BL: Malaria attributable to the HIV-I epidemic, subSaharan Africa. Emerg Infect Dis 2005, II:1410-1419.

7. Abu-Raddad LI, Patnaik P, Kublin JG: Dual infection with HIV and malaria fuels the spread of both diseases in sub-Saharan Africa. Science 2006, 314:1603-1606.

8. Marsh K: Malaria disaster in Africa. Lancet 1998, 352:924.

9. White NJ, Nosten F, Looareesuwan S, Watkins WM, Marsh K, Snow RW, Kokwaro G, Ouma J, Hien TT, Molyneux ME, Taylor TE, Newbold Cl, Ruebush TK, Danis M, Greenwood BM, Anderson RM, Olliaro P: Averting a malaria disaster. Lancet 1999, 353:1965-1967.

10. RW S, MH C, Newton CRJC, RW S: The public health burden of Plasmodium falciparum malaria in Africa: deriving the numbers. Working Paper I I, Disease Control Priorities Project. In The Disease Control Priorities Project (DCPP) Working Paper Series Edited by: Bethesda . Maryland, Fogarty International Center, National Institutes of Health;; 2003.

II. Beier JC, Killeen GF, Githure Jl: Short report: entomologic inoculation rates and Plasmodium falciparum malaria prevalence in Africa. Am J Trop Med Hyg 1999, 61:109-1 I3.

12. Nations U: World population prospects - the 2004 revision population database. New York, United Nations Population Division; 2002.

13. Kitchen SF: Symptomatology: general considerations and falciparum malaria. In Malariology Edited by: Boyd MF. Philadelphia, WB Saunders; 1949:996-1017.

14. E L, WA S, M A: LOG-normal distributions across the sciences: keys and clues. Bioscience 200I, 5 I:34I -352.

15. Greenwood B, Marsh K, Snow R: Why do some African children develop severe malaria? Parasitol Today 199I, 7:277-28I.

16. Grimwade K, French N, Mbatha DD, Zungu DD, Dedicoat M, Gilks CF: HIV infection as a cofactor for severe falciparum malaria in adults living in a region of unstable malaria transmission in South Africa. AIDS 2004, I 8:547-554.
17. Greenberg AE, Nsa W, Ryder RW, Medi M, Nzeza M, Kitadi N, Baangi $M$, Malanda N, Davachi F, Hassig SE: Plasmodium Falciparum malaria and perinatally acquired human immunodeficiency virus type I infection in Kinshasa, Zaire. A prospective, longitudinal cohort study of $\mathbf{5 8 7}$ children. N Engl J Med |99|, 325: 105-109.

18. Kalyesubula I, Musoke-Mudido P, Marum L, Bagenda D, Aceng E, Ndugwa $C$, Olness $K$ : Effects of malaria infection in human immunodeficiency virus type I-infected Ugandan children. Pediatr Infect Dis J 1997, 16:876-88I.

19. Otieno RO, Ouma C, Ong'echa JM, Keller CC, Were T, Waindi EN, Michaels MG, Day RD, Vulule JM, Perkins DJ: Increased severe anemia in HIV-I-exposed and HIV-I-positive infants and children during acute malaria. AIDS 2006, 20:275-280.

20. Ross A, Maire N, Molineaux L, Smith T: An epidemiologic model of severe morbidity and mortality caused by Plasmodium falciparum. Am J Trop Med Hyg 2006, 75:63-73.

21. French N, Nakiyingi J, Lugada E, Watera C, Whitworth JA, Gilks CF: Increasing rates of malarial fever with deteriorating immune status in HIV-I-infected Ugandan adults. AIDS 200I, 15:899-906.

22. Laufer MK, van Oosterhout J], Thesing PC, Thumba F, Zijlstra EE, Graham SM, Taylor TE, Plowe CV: Impact of HIV-associated immunosuppression on malaria infection and disease in Malawi. J Infect Dis 2006, 193:872-878.

23. Patnaik P, Jere CS, Miller WC, Hoffman IF, Wirima J, Pendame R, Meshnick SR, Taylor TE, Molyneux ME, Kublin JG: Effects of HIV-I serostatus, HIV-I RNA concentration, and CD4 cell count on the incidence of malaria infection in a cohort of adults in rural Malawi. J Infect Dis 2005, 192:984-99I.

24. van Geertruyden JP, Mulenga M, Kasongo W, Polman K, Colebunders R, Kestens L, D'Alessandro U: CD4 T-Cell Count and HIV-I Infection in Adults With Uncomplicated Malaria. J Acquir Immune Defic Syndr 2006, 43:363-367.

25. Khasnis AA, Karnad DR: Human immunodeficiency virus type I infection in patients with severe falciparum malaria in urban India. J Postgrad Med 2003, 49: I | 4- II7.

26. Cohen C, Karstaedt A, Frean J, Thomas J, Govender N, Prentice E, Dini L, Galpin J, Crewe-Brown H: Increased prevalence of severe malaria in HIV-infected adults in South Africa. Clin Infect Dis 2005, 41:1631-1637.

27. UNAIDS. Report on the global HIVIAIDS epidemic. Geneva, Joint United Nations Programme on HIVIAIDS (UNAIDS) Report No.:; 2006.

28. Asamoah-Odei E, Garcia Calleja JM, Boerma JT: HIV prevalence and trends in sub-Saharan Africa: no decline and large subregional differences. Lancet 2004, 364:35-40.

29. Law AM, Kelton WD: Simulation modeling and analysis MacGraw-Hill, 400 p.; 1982.

30. Team RDC: A Language and Environment for Statistical Computing. 2005 [http://www.r-project.org]. Vienna, Austria, R Foundation for Statistical Computing

31. White NJ, Pongtavornpinyo $\mathrm{W}$ : The de novo selection of drugresistant malaria parasites. Proc Biol Sci 2003, 270:545-554.

32. Snow RW, Craig M, Deichmann U, Marsh K: Estimating mortality, morbidity and disability due to malaria among Africa's nonpregnant population. Bull World Health Organ 1999, 77:624-640.

33. White NJ: Antimalarial drug resistance. J Clin Invest 2004, I I 3:1084-1092.

34. Hastings IM: Complex dynamics and stability of resistance to antimalarial drugs. Parasitology 2006, 132:6| 5-624.

35. Nosten F, Brasseur P: Combination therapy for malaria: the way forward? Drugs 2002, 62:1315-1329.

36. Birku Y, Mekonnen E, Bjorkman A, Wolday D: Delayed clearance of Plasmodium falciparum in patients with human immunodeficiency virus co-infection treated with artemisinin. Ethiop Med J 2002, 40 Suppl I: 17-26.

37. van Geertruyden JP, Mulenga M, Mwananyanda L, Chalwe V, Moerman F, Chilengi R, Kasongo W, Van Overmeir C, Dujardin JC, Colebunders R, Kestens L, D'Alessandro U: HIV-I immune suppression and antimalarial treatment outcome in Zambian adults with uncomplicated malaria. J Infect Dis 2006, 194:917-925

38. Shah SN, Smith EE, Obonyo CO, Kain KC, Bloland PB, Slutsker L, Hamel MJ: HIV Immunosuppression and Antimalarial Efficacy: Sulfadoxine-Pyrimethamine for the Treatment of Uncom- 
plicated Malaria in HIV-Infected Adults in Siaya, Kenya. Infect Dis 2006, 194:1519-1528.

39. Hastings IM, D'Alessandro U: Modelling a predictable disaster: the rise and spread of drug-resistantmalaria. Parasitol Today 2000, 16:340-347.

40. Talisuna $A O$, Bloland $P, D$ 'Alessandro U: History, dynamics, and public health importance of malaria parasite resistance. Clin Microbiol Rev 2004, 17:235-254.

41. Organization WH, Fund UNC: World Malaria Report 2005. 2005 [http://rbm.who.int/wmr2005]. Geneva, Switzerland: World Health Organization (accessed Sept 9, 2007)

42. Mermin J, Ekwaru JP, Liechty CA, Were W, Downing R, Ransom R, Weidle P, Lule J, Coutinho A, Solberg P: Effect of co-trimoxazole prophylaxis, antiretroviral therapy, and insecticide-treated bednets on the frequency of malaria in HIV-I-infected adults in Uganda: a prospective cohort study. Lancet 2006, 367:|256-|26|.

43. Mermin J, Lule J, Ekwaru JP, Downing R, Hughes P, Bunnell R, Malamba S, Ransom R, Kaharuza F, Coutinho A, Kigozi A, Quick R: Cotrimoxazole prophylaxis by HIV-infected persons in Uganda reduces morbidity and mortality among HIV-uninfected family members. AIDS 2005, 19:1035-1042.

44. Killeen GF, Smith TA, Ferguson HM, Mshinda $H$, Abdulla $S$, Lengeler C, Kachur SP: Preventing childhood malaria in Africa by protecting adults from mosquitoes with insecticide-treated nets. PLoS Med 2007, 4:e229.

45. Shaffer N, Hedberg K, Davachi F, Lyamba B, Breman JG, Masisa OS, Behets F, Hightower A, Nguyen-Dinh P: Trends and risk factors for HIV-I seropositivity among outpatient children, Kinshasa, Zaire. AIDS 1990, 4:123I-I 236.

46. Mermin J, Lule J, Ekwaru JP, Malamba S, Downing R, Ransom R, Kaharuza F, Culver D, Kizito F, Bunnell R, Kigozi A, Nakanjako D, Wafula W, Quick R: Effect of co-trimoxazole prophylaxis on morbidity, mortality, CD4-cell count, and viral load in HIV infection in rural Uganda. Lancet 2004, 364: | 428-1434.

47. Kamya MR, Gasasira AF, Yeka A, Bakyaita N, Nsobya SL, Francis D, Rosenthal PJ, Dorsey G, Havlir D: Effect of HIV-I infection on antimalarial treatment outcomes in Uganda: a populationbased study. J Infect Dis 2006, 193:9-15.

48. Taha TE, Canner JK, Dallabetta GA, Chiphangwi JD, Liomba G, Wangel AM, Saah AJ, Miotti PG: Childhood malaria parasitaemia and human immunodeficiency virus infection in Malawi. Trans $R$ Soc Trop Med Hyg 1994, 88: $164-165$.

49. Colebunders R, Bahwe Y, Nekwei W, Ryder R, Perriens J, Nsimba K, Turner A, Francis H, Lebughe I, van der SP: Incidence of malaria and efficacy of oral quinine in patients recently infected with human immunodeficiency virus in Kinshasa, Zaire. J Infect 1990, 21:167-173.

50. Muller O, Moser R: The clinical and parasitological presentation of Plasmodium falciparum malaria in Uganda is unaffected by HIV-I infection. Trans $R$ Soc Trop Med Hyg 1990, 84:336-338.

51. Simooya OO, Mwendapole RM, Siziya S, Fleming AF: Relation between falciparum malaria and HIV seropositivity in Ndola, Zambia. BMJ 1988, 297:30-31.

52. Grimwade K, French N, Mbatha DD, Zungu DD, Dedicoat M, Gilks CF: Childhood malaria in a region of unstable transmission and high human immunodeficiency virus prevalence. Pediatr Infect Dis J 2003, 22:1057-1063.
Publish with Biomed Central and every scientist can read your work free of charge

"BioMed Central will be the most significant development for disseminating the results of biomedical research in our lifetime. "

Sir Paul Nurse, Cancer Research UK

Your research papers will be:

- available free of charge to the entire biomedical community

- peer reviewed and published immediately upon acceptance

- cited in PubMed and archived on PubMed Central

- yours - you keep the copyright

Submit your manuscript here:

http://www.biomedcentral.com/info/publishing_adv.asp
BioMedcentral 